\title{
IDENTIFIKASI FAIR USE/FAIR DEALING HAK CIPTA ATAS BUKU DALAM PENGEMBANGAN IPTEK PADA PENDIDIKAN TINGGI DI JAWA TENGAH
}

\author{
Anis Mashdurohatun dan M. Ali Mansyur \\ Fakultas Hukum Universitas Islam Sultan Agung \\ e-mail : anism@unissula.ac.id; m_alimansyur@yahoo.co.id.
}

\begin{abstract}
The purpose of this research is identified the implementation of fair use/ fair dealingof book's copyright of science and technology book on High Education in Central Java. This research conducted by sociological and juridical approach. The sampling technique with purposive nonrandom sampling. The data collection is used with literature study and field (observation, questionaires, and interview) for the author and users book. Analizing data is used with qualitative desctription analizing. The result shows that identification of implementation fair use/fair dealing of book's copyright for development science and technology in High Education in Central Java has some problem with perception of users's book society at Salatiga, Semarang District and the Semarang City, that cause of offence of book's copyright, and low reward of moral rights and economic rights of creators/holders, also reading habit of people are low and purchasing power of people for books are very low, so because of it development of science and technology in High Education are needed fair use/fair dealing policy model of book's copyrights of developing science and technology in High Education in Central Java with based balance rights value and utilization of books easy, which qualified in form of text books and e-Books in affordable price.
\end{abstract}

Keyword : fair use/fair dealing, book's copyrights, science and technology, and High Education.

\begin{abstract}
Abstrak
Tujuan penelitian adalah untuk mengidentifikasi implementasifair use/ fair dealinghak cipta atas buku pengembangan IPTEK pada Pendidikan Tinggidi Jawa Tengah. Penelitian ini dilakukan dengan menggunakan pendekatan yuridis sosiologis. Teknik pengambilan sampel dengan menggunakan purposive nonrandom sampling. Adapun pengumpulan data dilakukan dengan studi kepustakaan dan lapangan (observasi, kuesioner dan wawancara) terhadap penulis dan pengguna buku. Analisis data dilakukan dengan menggunakan analisis deskriptif kualitatif. Hasil penelitian menunjukkan bahwa identifikasi implementasi fair use/fair dealing hak cipta atas buku dalam pengembangan IPTEK pada pendidikan tinggi di Jawa Tengah terkendala dengan beragamnya persepsi masyarakat pengguna buku di Salatiga, Kabupaten Semarang dan Kota Semarang, sehingga memicu terjadinya pelanggaran hak cipta atas buku, dan rendahnya penghargaan hak moral dan hak ekonomi pencipta/pemegang hak cipta, selain itu juga reading habit masyarakat yang rendah dan daya beli masyarakat terhadap buku masih sangat rendah, oleh karena itu dalam pengembangan IPTEK pada Pendidikan Tinggi diperlukannya kebijakan model fair use/fair dealing hak cipta atas buku dalam pengembangan IPTEK pada pendidikan tinggi di Jawa Tengah dengan berasaskan keseimbangan hak dan pemanfaatan buku yang menjamin aksebilitas buku mudah, yang berkualitas dalam bentuk buku teks dan $e$-Books dengan harga yang terjangkau.
\end{abstract}

Kata kunci : fair use/fair dealing, hak cipta buku, IPTEK dan Pendidikan Tinggi.

\section{A. Pendahuluan}

Hak cipta merupakan bagian dari Hak Kekayaan Intelektual (HKI) yang memiliki dua hak yakni hak moral dan hak ekonomi. Eric M. Dobrusin dan Ronald A. Krasnon (Eric M. Dobrusin 
dan Ronald A. Krasnon, 2008: 8) menyatakan bahwa Hak Cipta merupakan hak eksklusif bagi pencipta atau pemegang hak cipta untuk mengumumkan atau memperbanyak ciptaan yang timbul secara otomatis setelah ciptaan selesai dilahirkan tanpa mengurangi pembatasan menurut perundang-undangan yang berlaku. Buku merupakan salah satu jenis ciptaan yang dilindungi hak cipta (Pasal 40 ayat (1) Undang-Undang Nomor 28 Tahun 2014 tentang Hak Cipta - UU Hak Cipta). Fair use/fair dealing, pada umumnya diterapkan oleh banyak negara yang memungkinkan perbanyakan ciptaan,tetapi tidak dikualifikasikansebagai pelanggaran hak cipta (Sanusi Bintang,1998:49).

Negara Indonesia lebih lazim dengan menggunakan Fair use/fair dealing dengan istilah Pembatasan hak cipta. Berdasarkan pada ketentuan UU Hak Cipta tersebut pada BAB VI Pembatasan Hak Cipta (Fair Use/Fair Dealing), Pasal 43 s.d Pasal 49. Fair Use/Fair Dealing hak cipta atas buku adalah sebagai berikut :

Pasal 44

(1) Penggunaan, pengambilan, Penggandaan, dan/atau pengubahan suatu Ciptaan dan/atau produk Hak Terkait secara seluruh atau sebagian yang substansial tidak dianggap sebagai pelanggaran Hak Cipta jika sumbernya disebutkan atau dicantumkan secara lengkap untuk keperluan:

a. pendidikan, penelitian, penulisan karya ilmiah, penyusunan laporan, penulisan kritik atau tinjauan suatu masalah dengan tidak merugikan kepentingan yang wajar dari Pencipta atau Pemegang Hak Cipta;

b. keamanan serta penyelenggaraan pemerintahan, legislatif, dan peradilan;

c. ceramah yang hanya untuk tujuan pendidikan dan ilmu pengetahuan; atau

d. pertunjukan atau pementasan yang tidak dipungut bayaran dengan ketentuan tidak merugikan kepentingan yang wajar dari Pencipta.

Pasal 46

(1) Penggandaan untuk kepentingan pribadi atas Ciptaan yang telah dilakukan Pengumuman hanya dapat dibuat sebanyak 1 (satu) salinan dan dapat dilakukan tanpa izin Pencipta atau Pemegang Hak Cipta.

(2) Penggandaan untuk kepentingan pribadi sebagaimana dimaksud pada ayat (1) tidak mencakup:

a. karya arsitektur dalam bentuk bangunan atau konstruksi lain;

b. seluruh atau bagian yang substansial dari suatu buku atau notasi musik;

c. seluruh atau bagian substansial dari database dalam bentuk digital;

d. Program Komputer, kecuali sebagaimana dimaksud dalam Pasal 45 ayat (1); dan

e. Penggandaan untuk kepentingan pribadi yang pelaksanaannya bertentangan dengan kepentingan yang wajar dari Pencipta atau Pemegang Hak Cipta.

Pasal 47

Setiap perpustakaan atau lembaga arsip yang tidak bertujuan komersial dapat membuat 1 (satu) salinan Ciptaan atau bagian Ciptaan tanpa izin Pencipta atau Pemegang Hak Cipta dengan cara:

a. Penggandaan tulisan secara reprografi yang telah dilakukan Pengumuman, diringkas, atau dirangkum untuk memenuhi permintaan seseorang dengan syarat:

1. perpustakaan atau lembaga arsip menjamin bahwa salinan tersebut hanya akan digunakan untuk tujuan pendidikan atau penelitian; 
2. Penggandaan tersebut dilakukan secara terpisah dan jika dilakukan secara berulang, Penggandaan tersebut harus merupakan kejadian yang tidak saling berhubungan; dan

3. tidak ada Lisensi yang ditawarkan oleh Lembaga Manajemen Kolektif kepada perpustakaan atau lembaga arsip sehubungan dengan bagian yang digandakan.

b. Pembuatan salinan dilakukan untuk pemeliharaan, penggantian salinan yang diperlukan, atau penggantian salinan dalam hal salinan hilang, rusak, atau musnah dari koleksi permanen di perpustakaan atau lembaga arsip lain dengan syarat:

1. perpustakan atau lembaga arsip tidak mungkin memperoleh salinan dalam kondisi wajar; atau

2. pembuatan salinan tersebut dilakukan secara terpisah atau jika dilakukan secara berulang, pembuatan salinan tersebut harus merupakan kejadian yang tidak saling berhubungan.

c. Pembuatan salinan dimaksudkan untuk Komunikasi atau pertukaran informasi antarperpustakaan, antarlembaga arsip, serta antara perpustakaan dan lembaga arsip.

Berdasarkan doktrin fair use/fair dealing tersebut diatas mengandung maksud tiga hal yakni: cara, tujuan dan substansi dalam menggunakan hak cipta atas buku. Oleh karena itu aktivitas penggandaan buku dengan melakukan foto kopi sebagaimana banyak dilakukan mahasiswa dan tenaga pengajar di banyak perguruan tinggi walaupun dengan alasan untuk kepentingan pendidikan, apabila tidak mendasarkan pada tidak hal tersebut bisa jadi termasuk tindakan yang melanggar hak cipta. Tingkat kesadaran masyarakat untuk menghargai hak cipta pada karya buku di dunia akademis masih rendah. Ini terlihat dari masih maraknya perbanyakan buku tanpa izin dan kasuskasus plagiarisme karya ilmiah baik di lingkungan perguruan tinggi maupun masyarakat awam.Pada tahun 2011 hasil laporan UNESCO se-Asia Pasifik menyatakan 13 juta penduduk Indonesia masih belum melek huruf (Anis Mashdurohatun, 2013:15).

Terjadinya potensi pelanggaran hak cipta padamasyarakat,disebabkan salah dalam menafsirkan maupun ketidaktahuan/kurangnya pemahaman HKI dan kultur masyarakat yang sangat berbeda (Agus Sardjono, 2009:49; Gatot Supramono, 2010:78; Anis Mashdurohatun, 2011:25). Kultur masyarakat Indonesia atau bangsa timur, cenderung lebih komunal, spiritual dan inklusif, sedangkan dalam sistem hukum HKI (termasuk di dalamnya hak cipta) cenderung lebih individulistik, matrialistik dan eksklusif (Anis Mashdurohatun,2013:14; Hayyan Ulhaq, 2011: 15). Kultur/budaya tersebut bukan merupakan budaya pribadi, melainkan budaya menyeluruh dari masyarakat tertentu sebagai satu kesatuan sikap dan perilaku (Eman Suparman,2012:20). Perlindungan HKI(termasuk Hak Cipta) bertujuan untuk mendorong timbulnya kreatifitas baru/ inovasi, pengalihan dan penyebaran IPTEK, memberikan manfaat ekonomi, serta menciptakan kesejahteraan sosial dan ekonomi serta keseimbangan hak dan kewajiban (Elisabert Nurhaini Butarbutar,2012:53).

Dengan mendasarkan pada uraian latar belakang masalah, secara rinci dapat diambil permasalahan yakni bagaimanakah identifikasi implementasi fair use/fair dealing Hak Cipta atas Buku dalam pengembangan IPTEK pada Perguruan Tinggi di Jawa Tengah saat ini? Dimana hal ini sangat penting sebagai dasar dalam rangka menyusun draf model fairuse/fair dealing Hak Cipta atas Buku dalam pengembangan IPTEK pada Perguruan Tinggi.

\section{B. Metode Penelitian}

Penelitian ini dilakukan dengan menggunakan pendekatan yuridis sosiologis. Teknik pengambilan sampel dengan menggunakan purposive nonrandom sampling. Adapun pengumpulan 
data dilakukan dengan studi kepustakaan dan lapangan (melalui observasi, kuesioner dan wawancara) terhadap penulis dan pengguna buku. Analisis data dilakukan dengan menggunakan analisis diskriptif kualitatif.

\section{Hasil Penelitian dan Pembahasan}

1. Identifikasi Fair Use/Fair Dealing Hak Cipta Atas Buku Dalam Pengembangan IPTEK Pada Pendidikan Tinggi di Jawa Tengah.

Adapun identifikasi implementasi Fair Use/Fair Dealing Hak Cipta atas Buku dalam pengembangan IPTEK pada Perguruan Tinggi di Jawa Tengah khususnya pada PTN dan PTS di Semarang, Kabupaten Semarang dan Salatiga dilihat dari aspek pengguna buku diantaranya penerbit, pencipta/pengarang, dosen, dan mahasiswa, lembaga perpustakaan, serta pengusaha foto kopi adalah sebagai berikut:

a. Indentifikasi Implementasi Fair Use/Fair Dealing Hak Cipta atas Buku dalam pengembangan IPTEK oleh IKAPI sebagai Penerbit Buku

Untuk meningkatkan derajat tenaga kerja yang dikirim ke luar negeri, tentunya harus dengan meningkatkan kualitas sumber daya manusia yang memiliki ilmu pengetahuan dan teknologi sebagai skill (Ajip Rasidi,2006:xx). Ilmu pengetahuan, seni dan sastra, merupakan ruang lingkup dari hak cipta. Dalam bidang tersebut, harus diakui bahwa Indonesia masih banyak memerlukan berbagai keahlian dan ilmu pengetahuan, metoda dan hasil-hasil kegiatan penelitian dan pengembangan dari bangsa lain (Hasil wawancara Siswanto, IKAPI Jateng, 26 Juni 2015).

Dengan mendasarkan ketentuan fair use/fair dealing pada Pasal 43 UU Hak Cipta pemerintah bisa melakukan penggandaan dan sebagaimana melalui penerbit yang diberi wewenang, dan tindakan tersebut tidak dianggap pelanggaran hak cipta.Pasal 43 huruf a menyebutkan bahwa Perbuatan yang tidak dianggap sebagai pelanggaran Hak Cipta meliputi:Pengumuman, Pendistribusian, Komunikasi, dan/atau Penggandaan segala sesuatu yang dilaksanakan oleh atau atas nama pemerintah, kecuali dinyatakan dilindungi oleh peraturan perundang-undangan, pernyataan pada Ciptaan tersebut, atau ketika terhadap Ciptaan tersebut dilakukan Pengumuman, Pendistribusian, Komunikasi, dan/atau Penggandaan.

Sejauh ini IKAPI selaku penerbit belum mendapatkan kewenangan dari pemerintah untuk menerbitkan buku-buku khusus dalam pendidikan tinggi, bahkan untuk menerjemahkan maupun menyadur buku-buku dalam bahasa asing. IKAPI dalam membantu mengusahakan terwujudnya bangsa yang cerdas, yang mempunyai kreatifitas yang tinggi, masih terkendala dikarenakan beberapa hal, diantaranya sebagai berikut:Rendahnya pengetahuan karya Intelektual manusia, belum terciptanya kesadaran menghargai hak cipta orang lain, tidak adanya penegakan yang tegas bagi para pembajak, mematikan ide kreatifitas masyarakat, lesunya gairah dalam berkarya dalam menulis buku, dan tingkat pemahaman HKI khususnya hak cipta dikalangan aparat penegak hukum yang masih beragam.

Bangsa Indonesia merupakan bangsa yang berke-Tuhanan Yang Maha Esa, yang mempunyai rasa kebersamaan yang dikenal dengan gotong-royong. Maka sudah selayaknyalah value ke-Indonesi-an lebih dikedepankan dalam membangun peradaban bangsa dalam pengembangan dan pemanfaatan ilmu pengetahuan melalui buku sebagai upaya mencerdaskan kehidupan bangsa dan meningkatkan kesejahteraan umum perlunya kerjasama dengan masing-masing pihak demi terwujudnya cita-cita bangsa Indonesia yang 
luhur dan mulia. Dalam menumbuhkan kembangkan kreatifitas masyarakat suatu bangsa IKAPI terkendala oleh beberapa hal, diantaranya:Kesadaran penghargaan terhadap suatu karya cipta yang tinggi, Masih rendahnya minat membaca masyarakat, Masyarakat lebih berminat membaca buku yang non pendidikan atau ilmu pengetahuan, Belum terealisasinya Perlindungan Hukum terhadap para pencipta /pun pemegang hak cipta yang baik, Budaya menghargai ciptaan buku dengan tidak memfoto kopi, Seringnya buku dibajak dan tidak ada punishment, Sementara penerbit yang harus membayar pajak dan bila terlambat membayar pajak terkena denda, Kebijakan pemerintah belum mendukung harga buku yang terjangkau, Oplah buku yang masih sedikit dan belum merata, Ketersedian distribusi buku yang masih terbatas, Masih perlunya peningkatan mutu/kualitas naskah buku dari penulis, Belum baiknya iklim pemanfaatan buku pada seluruh masyarakat (Hasil wawancara Kartini Nurdin IKAPI Pusat,7 Juni 2015).

Ajip Rosidi mengatakan bahwa para penerbit buku yang tergabung dalam Ikapi berkiprah mempunyai visi dalam ikut serta mengusahakan mencerdaskan kehidupan bangsa Indonesia dalam meningkatkan kualitas rohani dan lahiriyah masyarakat di seluruh nusantara, namun dalam prakteknya terkendala, disebabkan beberapa hal, diantaranya yaitu: kemampuan finansial masyarakat kita masih sangat rendah untuk membeli buku,tidak ada usaha pembangunan perpustakaan yang memadai baik oleh pemerintah maupun oleh lembaga-lembaga swasta, Perusahaan-perusahaan besar di Indonesia tidak ada yang memulai langkah pembentukan perpustakaan yang menyediakan bacaan yang bermanfaat bagi rakyat banyak seperti Carnegie di Amerika Serikat, Pemerintah belum membuat undang-undang yang meringankan pajak para pengusaha jika sebagian keuntungannya digunakan untuk mendanai perpustakaan atau kegiatan-kegiatan sosialbudaya yang lain, Tingkat kegemaran membaca masyarakat yang rendah, ditambah oleh kemampuan finansialnya yang sangat terbatas, tidaklah menjanjikan akan menghasilkan untung yang menarik, Dilema adanya pembajakan buku, Rendahnya kesadaran penghargaan karya cipta masyarakat, termasuk para pencipta dan penerbit, para pejabat pemerintah dan para penegak hukum dan juga kaum legislatif dan yudikatif, Pentingnya Penerbitan buku dengan edisi bahasa asing melalui kerjasama Asia/Pacific Cutural Centre for UNESCO, Jepang, Perlunya menumbuhkan pengertian dan kesadaran akan fungsi hak cipta dalam masyarakat (Ajip Rasidi, 2006: xxix).

Dalam kehidupan masyarakat hubungan antar sesama akan terjadi menyertai kehidupannya, dan antar masing-masing individu akan melahirkan hubungan hukum. Agar hubungan hukum tersebut dapat berjalan lancar, maka perlu adanya keterwujudan keadilan dalam masyarakat.Perjanjian yang isinya dibakukan dan dituangkan dalam bentuk formulir, dengan mendasarkan asas kebebasan berkontrak dapat dibenarkan manakala tidak diikuti dengan klausul yang menyebabkan terjadinya penyimpangan terhadap asas keseimbangan, asas kesamaan hukum dan asas tanggung jawab (Ali Mansyur,2010: 1-2).

Pada prinsipnya IKAPI dalam melaksanakan kontrak dengan penulis buku tetap mengacu pada ketentuan perundang-undangan yang berlaku, sebagaimana ketentuan Pasal 1320 KUH Perdata, Perjanjian dinyatakan sah apabila telah memenuhi syarat-syarat sebagai berikut:Sepakat mereka yang mengikatkan diri, Kecakapan untuk membuat perjanjian, Suatu hal tertentu dan Suatu sebab yang halal.

Ketentuan fair use/fair dealing hak cipta atas buku sebagaimana telah diamanahkan dalam UU Hak Cipta belum dipahami secara menyeluruh oleh semua IKAPI sebagai penerbit buku, selain itu tidak semua penerbit menjadi anggota IKAPI.IKAPI hanya lebih 
memami kewajibannya sebagai pelaku usaha/perusahaan khususnya berkaitan dengan tanggung jawab sosial perusahaan (CSR)sebagaimana diamanatkan dalam UUNomor 40 Tahun 2007 tentang Perseroan Terbatas, Pasal 1 angka 3 di jelaskan bahwa tanggung jawab sosial dan lingkungan adalah komitmen perseroan untuk berperan serta dalam pembangunan ekonomi berkelanjutan guna meningkatkan kualitas kehidupan dan lingkungan yang bermanfaat, baik bagi perseroan sendiri, komunitas setempat, maupun masyarakat pada umumnya.Sejauh ini kegiatan sosial yang dilakukan lebih cenderung menggunakan dana CSR untuk lounching buku, yang bertujuan untuk pemasaran produkproduk buku baru serta cuci gudang buku-buku lama yang belum terjual, hal ini IKAPI/penerbit lakukan sebagai salah satu langkah manajemen perusahan untuk pengembalian modal perusahaan.

IKAPI sebagai Penerbit yang juga menjadi tangan panjang pemerintah, secara umum mempunyai beberapa kendala baik karena faktor internal maupun ekternal dalam melaksanakan kegiatan penerbitan buku. Adapun faktor internalnya terdiri dari Permodalan, Biaya operasional tinggi, Pendistributionnya masih sangat terbatas dan masih terkotak-kotak hanya dalam wilayah tertentu, serta tingginya kompetisi baik antar penerbit dalam negeri maupun luar negeri. Sedangkan untuk faktor eksternal terdiri dari Rendahnya daya beli, Masyarakat lebih senang buku non IPTEK, Oplah buku tidak sebanding dengan jumlah penduduk Indonesia, Kualitas substansi buku masih rendah, Belum bisa memberikan royalty yang layak, Masyarakat lebih senang foto kopi atau buku bajakan, Bajakan buku banyak beredar serta kebijakan Pemerintah belum sepenuhnya menguntungkan penerbit secara umum. Pada prinsipnya penerbit hal tersebut sangat merugikan eksistensi IKAPI selaku penerbit/pemegang hak cipta.

b. Indentifikasi implentasi fair use/fair dealing Hak Cipta atas Buku dalampengembangan IPTEK pada Perguruan Tinggi di Jawa Tengah oleh Pencipta/Pengarang Buku

Secara umum baik penulis buku, dosen dan mahasiswa pada pendidikan tinggi sangat memahami arti pentingnya buku dalam pengembangan IPTEK. Namun tidak semuanya memahami bahwasanya buku merupakan salah satu ciptaan yang di lindungi sebagaimana dijabarkan dalam Pasal 40 ayat (1) UU Hak Cipta.Selain itu juga berkaitan dengan ketentuan fair use/fair dealing hak cipta atas buku sebagaimana diatur Pasal 44 ayat (1) huruf a, huruf b, dan huruf c yang lebih memberikan perlindungan hak moral pencipta. Kemudian ketentuan Pasal 46 ayat (1) dan ayat (2) huruf b dan huruf e lebih memberikan perlindungan hak ekonomi pencipta/pemegang hak cipta.

Pesatnya perkembangan teknologi dalam dekade terakhir ini, pastinya telah memberikan dampak dalam pengembangan IPTEK di semua bidang, baik positif maupun negatif yang sangat signifikan, terlebih lagi bagi mahasiswa dan dosen pada perguruan tinggi dalam menggunakan resourcepada internet/website yang tersedia. Berkenaan dengan buku teks selama ini pengarang/penulis buku merasa lesu dan kurang bergairah, hal ini lebih dipicu dikarenakan beberapa hal diantaranya, yaitu: penghargaan kepada penulis sangat rendah atau sangat tidak layak, mahasiswa lebih suka yang instan, mahasiswa lebih suka copy pastepada internet, penerbit hanya memberikan royalti sekali saja pada penulis, dan ironisnya banyak sekali penulis buku justru harus memberikan fee kepada penerbit untuk memperbanyak/menggandakan dan mengumumkan buku tersebut secara luas.Ciri khas/bagian substansial dari bukunya adalah pada ide judul buku dan dalam bab pembahasan, hal tersebut senada yang diungkapkan oleh Ibu Maya Dosen di Fakultas 
Hukum UKSW, lebih lanjut menuturkan bahwasanya dia sangat memahami buku merupakan hak cipta namun tidak memahami maupun mengetahui secara jelas adanya fair use/fair dealing atas buku. buku merupakan ciptaan yang dilindungi Hak cipta. Civitas akedemika tidak boleh foto kopibuku karena melanggar Hak Cipta(Hasil wawancara Dekan Fakultas Hukum UKSW, Maret 2015).

Pentingnya buku sebagai suatu ilmu pengetahuan sebagai sumber referensi, Selaku Penulis Buku Dr Suparmin sebagai dosen sekaligus Dekan Fakultas Hukum UNWAHAS Semarang, menyatakan penghargaaan secara ekonomi belum layak dan buku-bukunya sering dibajak. Meng-copy buku tidak lebih dari 15\%, dengan tujuan tidak komersial untuk pengembangan IPTEK. Perpustakaan sebagai sumber referensi dosen dan mahasiwa dalam mencerdaskan kehidupan suatu bangsa. Perlunya peningkatan kuantitas dan kualitas setiap buku dengan harga terjangkau serta mudah dalam mengakses (Hasil wawancara Penulis Buku Suparmin, Junaidi,Abdul Kholid Dahlan Perguruan Tinggi Kab.Semarang dan Kota Semarang, Mei 2015)

Teguh Prasetyo, Guru besar Fakultas Hukum UKSW Salatiga, telah menghasil karya buku kurang lebih 20 buah karya buku, diantaranya berkisar tentang masalah pidana, antara lain Huku Pidana, Hukum Acara Pidana, HukumPidana Militer, Hukum Pidana Anak, Kriminologi, Korupsi dan Illegal Logging, Bisnis E-commerce, Hukum Islam Menjawab Tantangan Zaman, Ilmu Hukum dan Filsafat Hukum, serta kriminalisasi Hukum Pidana. Model kutipannya dalam bukunya dengan menggunakan footnote atau catatan kaki sebagaimana ketentuan dalam UU Hak Cipta.

Setiap dosen mempunyai tugas Tridarma Perguruan Tinggi, oleh karena itu pengabdian dan sharing knowlege merupakan bagian dari tugas dosen, hal ini juga merupakan prinsip dari Heru S, Dosen di Fakultas Ekonomi UNISSULA sekaligus sebagai seorang penulis buku. Buku menurutnya sebagai wujud ilmu pengetahuan yang terus menerus perlu dikembangkan. Di dalam buku-buku nya beliou yang merupakan hasil riset dan pengembangan modul, bahan ajar atau diktat di bidang ilmu managemen ciri khas atau bagian yang menjadi substansialnya di dalam Bab Discussion dengan memasukan nilainilai Islam. Buku-buku tersebut diantaranya berjudul "Kepemimpinan Dalam Islam, Etos Kerja Islami, Managemen Islam dan Manajemen Strategik dalam Islam. Dalam hal keilmuan penyebaran pengetahuan adalah kewajiban bagi semua dosen dilingkungan pendidikan tinggi, namun dalam mengambil hasil karya orang lain adalah larangan, karena itu melanggar hak orang lain. Dengan demikian Heru S tidak setuju bila ada yang memfoto kopi/menyalin bukunya, itu sama hanya tidak menghargai karya ciptanya. Baginya kondisi saat ini ada penurunan mahasiswa dalam pengemangan ilmu, lebih-lebih dengan pesatnya perkembangan teknologi saat ini semua orang mengases karya-karya orang lain dengan sangat mudah dan cepat. Buku-buku tersebut masih di terbitkan di Sultan Agung Press (SAPress)(Hasil wawancara Penulis Buku Heru, Mei 2015).

Sejauh ini banyak anggapan bahwa menulis buku lebih banyak membutuhkan waktu lama karena terdiri dari Bab-Bab yang lebih dari 100 halaman, tentunya membutuhkan banyak sekali referensi, sementara itu KUM-nya juga kecil serta penghargaan ekomominya yang belum layak, maka orang cenderung untuk menulis artikel yang dipublikasikan dalam jurnal, karena jurnal tidak begitu ribet dan hanya 12-15 halaman. Namun bagi Heru S tidak demikian, menurutnya memang benar penghargaan secara ekonomi bagi penulis sejauh ini belum layak, dan membutuhkan waktu yang relatif panjang dalam menulis buku, tapi semuanya itu adalah keharusan dalam pengabdian dan sharing ilmu pengetahuan. Oleh 
karena itu menulis buku tetap dilaksanakan,penelitian, menulis jurnal serta membuat buku. Dalam hal citasi/kutipan dengan model menulis nama penulis dan tahun terbit serta halaman baru ditulis secara lengkap dalam Daftar Pustaka, sementara itu untuk mahasiswa dalam menulis skripsi dan tesispun juga menggunakan model yang sama. Belum adanya aksebilitas dalam menemukan buku referensi lebih-lebih apalagi kalau Mata Kuliah itu berkaitan dengan sub bagian dijadikan Mata Kuliah, hal ini dirasakan disaat ditugaskan oleh pimpinan fakultas untuk mengajar, beliou sangat kesulitan mencari referensi akhirnya mengambil Ebook dalam WEBSITE.

Abdullah Kelibdan Teguh Prasetyo dimana keduanya merupakan seorang Guru Besar, menulis buku merupakan kewajiban sebagai dosen, sehingga kalau tidak menghasilkan buku atau karya ada perasaan malu pada masyarakat pada umumnya dan mahasiswa pada khususnya. Buku-buku beliau hingga tahun 2015 sudah lebih dari 25 buku yang tersebar baik Indonesia, maupun Amerika dan Eropa. Buku-buku tersebut diterbitkan oleh Rajawalipress, Nusamedia Bandung, Pustaka Pelajar dan lainnya. Buku terakhir terbit dengan judul "Sistem Hukum Pancasila”. Buku “ Keadilan Bermartabat “. Cirri khas atau hal yang substansial dari buku tersebut adalah lahirnya ide keadilan bermartabat yang diilhami dari keadilan-keadilan yang lahir dari bangsa barat seperti John Rawls, Adam Smitt, Plato maupun Socrates yang lebih mencerminkan keadilan numerik/property, sementara itu keadilan bermartabat itu lebih mencerminkan nilai-nilai Pancasila, yang lebih "memanusiakan manusia”/“ngewongke uwong” sehingga merupakan keadilan yang mendasarkan pada nilai Ketuhanan Yang Maha Esa (Sila I), Sila II, dan Sila V yang bersifat bend. Beliau tidak tidak memperbolehkan bukunya difotokopi, karena menurutnya buku-bukunya juga banyak dibajak(Hasil wawancara dengan Abdullah Kelib dan Teguh Prasetyo, Mei 2015).

Dengan demikian berkaitan denganketentuan fair use/fair dealing Pasal 44 ayat (1) huruf a, huruf b dan huruf c lebih berkaitan dengan sitasi: substansi, cara dan tujuan. Substansinya: secara seluruh atau sebagian yang substansial. Caranya: Sumbernya disebutkan atau dicantumkan secara lengkap, maksudnya dengan menyebutkan, nama penulids/pencipta, Judul buku, Penerbit/pemegang hak cipta, kota, tahun dan halaman yang disitasi. Tujuan : pendidikan, penelitian, penulisan karya ilmiah, penyusunan laporan, penulisan kritik atau tinjauan suatu masalah dengan tidak merugikan kepentingan yang wajar dari Pencipta atau Pemegang Hak Cipta;keamanan serta penyelenggaraan pemerintahan, legislatif, dan peradilan; dan ceramah yang hanya untuk tujuan pendidikan dan ilmu pengetahuan. Sedangkan fair use/fair dealingPasal 46 ayat (1) dan ayat (2) huruf b dan huruf e berkaitan dengan penggandaan/memfoto kopi. Substansi: untuk kepentingan pribadi tidak lebih satu salinan, tidak mencakup seluruh atau bagian yang substansial dari suatu buku, Caranya: dengan memfoto kopi. Tujuan: Penggandaan untuk kepentingan pribadi yang pelaksanaannya tidak bertentangan dengan kepentingan yang wajar dari Pencipta atau Pemegang Hak Cipta.

c. Indentifikasi implentasi fair use/fair dealing Hak Cipta atas Buku dalam pengembangan IPTEK pada Perguruan Tinggi di Jawa Tengah Dosen dan mahasiswa

Sebelum abad ke-15, kebanyakan hasil karya merupakan buku-buku agama yang ditulis oleh penulis dari kalangan biarawan. Buku-bu tersebut membutuhkan tenaga penulis yang cakap dan kualifikasinya tak sembarangan. Personelnya pun cukup banyak untuk mengerjakannya.Kemudian pada tahun 1455, dengan ditemukannya mesin pencetak yang 
bergerak (Movable Type) oleh Gutenberg dan selanjutnya dikembangkan alat cetak press oleh William Caxton, pada saat itu seni cetak dapat dijalankan dengan bebas. Sehingga England sebagai kota yang penting untuk pusat percetakan di eropa.Sejarah berlanjut dan zamanpun berubah. Perkembangan pengaturan hak cipta telah menjadi isu Internasional karena menyangkut sumber ekonomi dan perdagangan dari suatu negara. Bagi negara yang sudah maju, keberhasilan suatu temuan (invensi) suatu karya telah banyak membawa keuntungan bagi negaranya selain untuk pencipta. Sementara itu pembajakan dan pemalsuan produk-produk yang sangat terkenal sangat merugikan penciptanya (Imam Sjahputra, 2007:113-115).

Buku merupakan media/alat sarana pendidikan yang sangat fundamental bagi sivitas akademika dalam pengembangan ilmu dan teknologi. Buku merupakan suatu kebutuhan yang tidak dapat dipisahkan bagi seorang mahasiswa, dimana kebutuhan tersebut merupakan sumber IPTEK yang dipakai oleh mahasiswa dalam penyusunan suatu karya ilmiah. Fungi Buku yang merupakan salah satu jendela dunia adalah suatu perumpamaan yang sangat tepat dalam menggambarkan besarnya kebutuhan buku dalam proses menciptakan seseorang lebih terpelajar. Karena dengan membacalah ilmu pengetahuan yang lebih luas akan didapatkan seseorang.

Peran pemerintah sangat besar dalam meningkatkan kesejahteraan ilmuwan yang produktif menulis suatu karya ilmiah dalam bentuk buku. Boleh mem-fotokopi hanya terbatas 1 (satu) halaman, asal tidak komersial untuk kepentingan pmbelajaran dengan harapan membiasakan diri untuk menghargai hak cipta. Kebiasaan menghargai karya cipta, pemberian hak ekonomi yang layak sebagai stimulan, selama ini baru 10\%:90\%. Namun kalau DIKTI sudah layak memberikan hak ekonomi pada pencipta. Penerbit selaku pemegang hak cipta perlu bekerjasama dengan perguruan tinggi. Perlu juga etika bagi pengusaha foto kopi dalam memfoto kopi buku. kebaharuannya buku yang menjadi hal yang paling substansial/cirri khas nya pada ide yang menginspirasi dan pembuatan secara metodologis. Sudah biasa membeli buku pada Amazon.com dan Gramedia online yang lebih terjamin kualitasnya. Hanya memperbolehkan 1 (satu) halamanuntuk satu buku/referensi serta masimal satu halaman dalam mencitasi (Wawancara dengan Saru Arifin, 7 Mei 2015)

Sampai sejauh ini pemberian royalti/penghargaan hak ekonomi kepada pencipta/penulis buku belum layak. Boleh memfoto kopi asal tidak dengan tujuan komersial, perlu mewajibkan mahasiswa dengan tugas-tugas membaca buku referensi. Memberikan buku referensinya dengan harga yang terjangkau. Serta mewajibkan dosen untu menulis buku. penerbit perlu bekerjasama dengan perguruan tinggi dalam mendapatkan naskah buku yang berkuliatas. Perlu ada sanksi bagi pengusaha foto kopiyang mengkopi buku tanpa izin dan memberikan royalty kepada penerbit selaku pemegang hak cipta/penulis buku (Hasil wawancara dengan Prajanto Wahyu Adi, Dosen FIK UDINUS, 8 Mei 2015).

Buku sebagai salah satu sarana untuk mendapatkan ilmu pengetahuan yang lebih banyak. Serta berfungsi memberikan gagasan/ide awal dalam menulis buku, referensi dalam mengajar dan penelitian, memberikan manfaat sebagai salah satu sumber ilmu pengetahuan. Perlu kemudahan dan kemurahan mendapatkan buku. mendorong banyaknya perpustakaan ditengah-tengah masyarakat dan memberikan kemudahan dalam peminjaman buku. perlunya membuka kran komunikasi dengan penerbit, memberikan royalty yang 
layak kepada penulis buku. perlunya edukasi dan sanksi terhadap pelanggar hak cipta (Hasil wawancara Sukarman, Dosen, 6 Mei 2015).

Arti pentingnya buku dalam pengembangan IPTEK sebagai penunjang Knowlege.Penghargaan hak ekonomi dan hak moral penulis/pencipta belum mendapatkan dalam arti yang sesungguhnya artinya belum layak/seharusnya. Buku boleh diambil dalam hal yang substansial untuk dicitasi sebanyak 10\% demikian halnya menggunakan referensi buku yang lainpun juga 10\%. Buku sebagai penunjang belajar mahasiswa didukung dengan meningkatnya referensi buku yang berada di perpustakaan. Selain itu buku sebagai bahan pengembangan konsep dalam memberikan transformasi ilmu kepada mahasiswa. Yang bermanfaat bagi mahasiswa dalam melengkapi untuk bahan bacaan dan lebih terukur dalam adequatnya sumber buku. Bagi dosen sangat bermanfaat dalam menambah referensi bahan ajar dan meningkatkan kemmpuan pemahaman seorang dosen. Dalam hal memfoto kopi buku mahasiswa hanya diperkenankan foto kopi hanya sebatas satu lembar atau dua lembar dan tidak diperkenankan memfoto kopi satu buku secara utuh. Regulasi Kebijakan pemerintah dan perguruan tinggi perlu adanya standar minimal dalam penguasaan jumlah buku. Perpustakaan harus memfasilitasi pemenuhan kebutuhan buku. Reward secara finansial dan penghargaan dalam penilaian poin harus dipertimbangkan lagi. Meningkatkan pelayanan buku dengan mudah dan murah, atau harga buku dan memfoto kopi tidak jauh berbeda. Adanya punishment yang jelas bagi yang berwajib sehingga orang akan jera dalam foto kopi (Hasil wawancara dengan Ahmad Kholid, Dosen,7 Mei 2015).

Dalam pengembangan IPTEK Buku penting sebagai penunjang dalam pembelajaran. Sulitnya mencari buku terutama buku asing harganya juga mahal. Mendapatkan buku dengan cara membeli di toko buku Gramedia dan Gunung Agung, melakukan download di e-book yang tersedia meminjam diperpustakaan dan juga memfoto kopi. Penghargaan kepada penulis buku secara ekonomi tidak layak bahkan secara moral mahasiswa dan dosen tidak mengetahui penulis aslinya buku. Mengkutip buku penulis tidak lebih dari $10 \%$ dan menggunakan referensinya buku yang lain juga tidak lebih dari 10\%. Mahasiwa seharusnya memfoto kopi bagian yang memang dibutuhkan dan dosen perlu membeli sendiri bukannya memfoto kopi buku. Dalam hal guna pengembangan IPTEK perpustakaan perlunya memelakukan up-date buku dan mensosialisasikan, memberikan penghargaan secara moral dan ekonomi yang layak kepada penulis buku, berkoordinasi penerbit dengan penulis perguruan tinggi dan ketentuan dalam UU Hak Cipta perlu dipatuhi (Hasil wawancara dengan Danang Wahyu Utomo, Dosen, 8 Mei 2015).

Berdasarkan wawancara dengan Responden mahasiswa menunjukkan 100\% responden pernah melakukan foto kopi buku tanpa izin kepada penulis asli. Faktor yang melatarbelakangi mahasiswa dikarenakan beberapa hal antara lain:Faktor lebih murah Fotocopi daripada harga buku, Sulitnya mencari buku yang asli, Foto kopi lebih mudah daripada membeli buku aslinya, Aksebilitas buku asli yang sulit, Harganya lebih mahal, Jauhnya toko buku, Dikampus tidak ada toko buku yang ada usaha foto kopi, dan Perpustakaan dalam meminjam buku terbatas dan dibatasi (Hasil wawancara dengan mahasiswa dengan berbagai disiplin ilmu/fakultas pada universitas Negeri dan Swasta di kabupaten Semarang, Kota Semarang dan Salatiga,Mei 2015).

Hasil observasi menunjukkan mahasiswa belum memahami mengenai fair use /fair dealing Hak Cipta atas Buku, memfoto kopi buku tanpa ijin penulis diperbolehkan dengan memenuhi syarat-syarat tertentu. Ketentuan fair use/fair dealing Pasal 44 ayat (1) huruf (a), huruf (b) dan huruf (c) lebih berkaitan dengan sitasi: substansi, cara dan tujuan. 
Substansinya: secara seluruh atau sebagian yang substansial. Caranya: Sumbernya disebutkan atau dicantumkan secara lengkap, maksudnya dengan menyebutkan, nama penulids/pencipta, Judul buku, Penerbit/pemegang hak cipta, kota, tahun dan halaman yang disitasi. Tujuan : pendidikan, penelitian, penulisan karya ilmiah, penyusunan laporan, penulisan kritik atau tinjauan suatu masalah dengan tidak merugikan kepentingan yang wajar dari Pencipta atau Pemegang Hak Cipta;keamanan serta penyelenggaraan pemerintahan, legislatif, dan peradilan; dan ceramah yang hanya untuk tujuan pendidikan dan ilmu pengetahuan. Sedangkan fair use/fair dealing Pasal 46 ayat (1) dan ayat (2) huruf huruf (b) dan huruf (e) berkaitan dengan penggandaan/memfoto kopi. Substansi: untuk kepentingan pribadi tidak lebih satu salinan, tidak mencakup seluruh atau bagian yang substansial dari suatu buku, Caranya: dengan memfoto kopi. Tujuan: Penggandaan untuk kepentingan pribadi yang pelaksanaannya tidak bertentangan dengan kepentingan yang wajar dari Pencipta atau Pemegang Hak Cipta.

Arif Sidhartadengan mengutip pendapat Meuwissen, menjelaskan secara umum membedakan antara keberlakuan idiil dan keberlakuan normatif. Ada tiga bentuk keberlakuan Normatif yang ketiga-tiganya saling berkaitan satu dengan yang lain. Ketiga bentuk tersebut adalah Keberlakuan Sosial atau Faktual, Yuridik dan Moral. Keberlakuan hukum normatif merupakan suatu fenomena majemuk, yang berarti bahwa semua dari tiga momen itu harus ada, sehingga jika salah satu dari tiga momen itu tidak ada, maka hilanglah keberlakuan dari hukum itu (Arif Sidharta, 2009:45-47).

Moh. Mahfudz MD menyatakanhukum tidak dapat hanya dipandang sebagai pasalpasal yang bersifat imperatif atau keharusan-harusan yang bersifat das sollen, melainkan harus dipandang subsistem yang dalam kenyataan (das sein) bukan tidak mungkin sangat ditentukan oleh politik, baik dalam perumusan materi dan pasal-pasalnya maupun dalam implentasi dan penegakannya (Moh. Mahfudz MD, 2009:9-10).

Hukum pada hakekatnya dapat bertumbuh kembang menjadi ilmu pengetahuan bilamana orang yang dapat membaca dan menulis tersedia dalam jumlah yang cukup memadai. Penemuan ilmu dan seni mencetak buku selama Renaissance juga merupakan suatu faktor yang menentukan dalam rangka penyebaran aturan-aturan hukum yang tertulis dan buku ilmu pengetahuan hukum. Tanpa ilmu dan seni mencetak buku, tampaknya hampir tidak mungkin membayangkan adanya suatu ilmu pengetahuan hukum yang modern(C.S.T. Kansil dan Cristine S.T. Kansil,2011:246-247).

Kejayaan renaissance, dengan merosotnya feodalisme, oleh para ahli dilihat sebagai wujud tuntutan terhadap hak-hak alamiah manusia untuk dijadikan sebagai kebutuhan dasar dan sekaligus menjadi realitas sosial yang umum, sehingga hak-hak alamiah merupakan hak yang harus dihormati penguasa dalam memerintah (Dossy Iskandar Prasetyo dan Bernard L.Tanya: 2011: 67-68). HKI merupakan wujud dari HAM sebagaimana Pendapat John Locke, bahwaPenguasa tidak dapat mengambil atau merampas hak milik seseorang begitu saja tanpa persetujuan yang bersangkutan, dan Penguasa berkewajiban untuk menegakkan keadilan dan mengambil keputusan tentang hak-hak kaula negaranya menurut undang-undang yang tetap (C.S.T. Kansil dan Cristine S.T. Kansil, 2011: 251-252).

Keterbatasan akses masyarakat terhadap harga buku yang terjangkau, bermutu, dalammemanfaatkan buku teksdalam bidang hukum,sosial, agama, kesehatan, eksax, dan sebagainya memicu terjadinya pelanggaran hak cipta sehingga pencipta/pemegang hak 
cipta atas bukubelum mendapatkan perlindungan dan kepastian hukum secara optimal serta fair use/fair dealing hak cipta yang belum dipahami oleh semua pihak.

d. Indentifikasi implentasi Fair Use/Fair Dealing Hak Cipta atas Buku dalam pengembangan IPTEK pada Perguruan Tinggi di Jawa Tengah oleh Lembaga Perpustakaan.

Perpustakaan sebagai wahana belajar sepanjang hayat mengembangkan potensi masyarakat agar menjadi manusia yang beriman dan bertakwa kepada Tuhan Yang Maha Esa, berakhlak mulia, sehat, berilmu, cakap, kreatif, mandiri, dan menjadi warga negara yang demokratis serta bertanggung jawab dalam mendukung penyelenggaraan pendidikan nasional. sebagai salah satu upaya untuk memajukan kebudayaan nasional, perpustakaan merupakan wahana pelestarian kekayaan budaya bangsa serta dalam rangka meningkatkan kecerdasan kehidupan bangsa, perlu ditumbuhkan budaya gemar membaca melalui pengembangan dan pendayagunaan perpustakaan sebagai sumber informasi yang berupa karya tulis, karya cetak, dan/atau karya rekam (Undang-Undang Nomor 43 Tahun 2007 tentang Perpustakaan - UU Perpustakaan).

Lembaga perpustakaan berfungsi sebagai pendukung dalam kegiatan proses belajar mengajar dan menjadi sumber referensi dalam penyusunan karya ilmiah skripsi, tesis dan disertasi. memfoto kopi buku sesuai dengan kebutuhan. Perpustakaan berfungsi sebagai media untuk menunjang keberhasilan dalam proses belajar mengajar,khususnya bagi dosen dalam melaksanakan Tri Dharma Perguruan Tinggi. Buku bagi dosen sangat bermanfaat untuk menambah dan pengembangan IPTEK. Perlu adanya pembatasan dalam memfoto kopi buku dan memperbanyak jumlah referensi buku dan minimalisasikan referensi internet kecuali jurnal Asing dan e-books. Bahkan dasar referensinya dalam penulisan harus dari buku dan melarang sumber dari internet. Buku perpustaakan meningkat dari sisi judul buku dan kuantitas eksemplarnya, buku yang berkualitas dan up-date serta ada kontrol dari pemerintah. Dengan memberikan izin memfoto kopi buku dengan memenuhi persyaratan tertentu. Perpustaakan perlu berlangganan jurnal on-line maupun E-Books. Memfoto kopi buku dengan syarat buku tersebut terbatas atau diluar jangkauan(Hasil wawancara lembaga Perpustakaan Miswan,Enung Yuliati, Anik Ambarwati, Umar Basuki, Supriyono, R. Hengky, Mei-Juni 2015).

Deklarasi WSIS World Summit of Information Society-WSIS, 12 Desember 2003, bertujuan membangun masyarakat informasi yang inklusif, berpusat pada manusia dan berorientasi secara khusus pada pembangunan. Setiap orang dapat mencipta, mengakses, menggunakan, dan berbagi informasi serta pengetahuan hingga memungkinkan setiap individu, komunitas, dan masyarakat luas menggunakan seluruh potensi mereka untuk pembangunan berkelanjutan yang bertujuan pada peningkatan mutu hidup.

Berdasarkan Pasal 31 ayat (2), Pasal 32, dan Pasal 28F UUD 1945, pemerintah perlu menyelenggarakan perpustakaan sebagai sarana yang paling demokratis untuk belajar sepanjang hayat demi memenuhi hak masyarakat untuk memperoleh informasi melalui layanan perpustakaan guna mencerdaskan kehidupan bangsa (Penjelasan UU Perpustakaan).Pengembangan dan pendayagunaan perpustakaan diarahkan pada meningkatnya kegemaran membaca masyarakat (reading habit society) menuju masyarakat belajar (learning society) yang berujung pada peningkatan kecerdasan kehidupan bangsa seperti disebutkan di atas. Oleh sebab itu, perpustakaan harus menyediakan koleksi yang lengkap dan mudah serta murah. Untuk memanfaatkannya, peran masyarakat dalam pengembangan dan pendayagunaan perpustakaan sangat penting sehingga perlu adanya 
dorongan dengan berbagai bentuk seperti pemberian penghargaan dan sejenisnya (Peraturan Pemerintah Nomor 24 Tahun 2014 tentang Pelaksanaan UU Perpustakaan).

Ketentuan fair use/fairdealing hak cipta atas buku yang bisa dilakukan oleh perpustakaan/selaku lembaga mengacu pada ketentuan Pasal 47 UU Hak Cipta.Secara umum responden menjelaskan, bahwa lembaga perpustakaan belum memahami adanya fair use/fair dealing hak cipta atas buku, sehingga belum secara maksimalkan pelaksanaan fair use/fair dealing hak cipta atas buku tersebut. Namun dengan alasan untuk kepentingan pendidikan buku sebagai bahan referensi dalam menulis karya ilmiah pegawai perpustakaan juga sering membantu/melayani mahasiswa/pun dosen maupun mahasiswa pada umumnya untuk memfoto kopi buku. Oleh karena itu kegiatan lembaga perpustakaan adalah sebagai berikut: perpustakaan menyimpan atau mengkoleksi/mengarsip buku dan karya ilmiah lainnya, membantu mahasiswa dalam memfoto kopi buku, mahasiswa juga foto kopi tesis, skripsi dan disertasi, adanya koleksi buku dalam bentuk foto kopi, lembaga memfoto kopi sesuai kebutuhan biasanya memfoto kopi buku sebanyak antara 5-10 buah buku, koleksi buku asing masih sedikit, belum semuanya memiliki koleksi e-books, dan belum ada koleksi buku semua dosen di Perguruan Tinggi (Hasil wawancara dengan Lembaga Perpustakaan di perguruan tinggi, 2015, Juni 2015).

e. Indentifikasi implentasi Fair Use/Fair Dealing Hak Cipta atas Buku dalam pengembangan IPTEK pada Perguruan Tinggi di Jawa Tengah Oleh Pengusaha foto kopi.

Digitalisasi memungkinkan kita membuat salinan dan mengubah suatu ciptaan dengan sangat mudah. Digitalisasi juga memungkinkan kita untuk mempertahankan kualitas secara konsisten dan konstan berapa puluh kalipun suatu ciptaan disalin, betapapun besar suatu ciptaan atau berapa lama pun waktu berlalu. Karena mutu setiap salinan sama dengan mutu ciptaan orisinal, salinan bahkan dapat diperbanyak lagi dari salinan. Ini melahirkan reaksi berantai, dalam arti makin banyak salinan yang dibuat dari salinan. Juga ada bahaya yang lebih besar, yakni pelanggaran hak terjemahan dan hak mempertahankan keutuhan suatu ciptaan karena digitalisasi memudahkan kita melakukan perubahan pada ciptaan orisinal. Sekarang dimungkinkan untuk mengeksploitasi suatu ciptaan berulang kali tanpa ada perubahan pada mutu, karena tingginya mutu medium rekaman, seperti memori hanya baca cakram padat (CD-ROM=compact disc read only memory), dan sebagainya. Undang-undang hak cipta di setiap negara sedang diperbaiki agar dapat mencakup sistem kompensasi dan pembatasan bagi pembuatan salinan untuk penggunaan pribadi, sebagai jawaban atas perubahan-perubahan luar biasa dalam jenisjenis eksploitasi, jumlah pelanggaran, dan sebagainya, yang disebabkan oleh digitalisasi (Ajip Rosidi, 2006: 44-45).

Adapun secara umum para pelaku usaha foto kopi mengatakan bahwa aktifitas penggandaan/memfoto kopi buku dilakukakan, sebagaimana berikut: Tidak memberikan royalty baik kepada pencipta maupun penerbit, dalam memfoto kopi buku tidak pernah ijin pencipta/pemegang hak cipta (penerbit), bahkan tidak paham siapa penerbitnya buku yang difoto kopi, dalam memfoto kopi buku sesuai dengan permintaan konsumen/mahasiswa, lebih memfoto kopi semua isi buku, terkadang-kadang hanya beberapa BAB dalam isi Buku, tidak memahami mengenai izin dalam memfoto kopi buku (Hasil wawancara Dimas Pengusaha foto kopi, Amirudin, Kiki, 11 Mei 2015).

Dalam teori ekonomi menegaskan bahwa dengan modal yang kecil dapat menghasilkan keuntungan yang sebanyak-banyaknya. Menjamurnya pengusaha foto kopi 
hampir disemua lingkungan perguruan tinggi ada pengusaha foto kopi. Hal ini tentunya tidak lepas dengan adanya kebutuhan masyarakat yang sangat tinggi atau biasa dikatakan antara produsen dan konsumen, antara permintaan dan penjualan. Kapanpun dan dimanapun ekonomi merupakan bagian integral dalam kehidupan manusia, karena faktanya manusia dalam memenuhi kebutuhan hidupnya dapat dicapai melalui aktivitas ekonomi (Didiek Ahmad Supardie,2015:1). Namun perlunya ditekan prinsip-prinsip aktivitas ekonomi dengan tidak melanggar hak cipta/hak milik orang lain, sehingga keseimbangan antara hak dan kewajiban menjadi sangat penting terwujud.

Dari hasil responden menunjukkan bahwa secara umum para pengusaha foto kopi sebagian besar:Tidak memahami HKI maupun Hak cipta, Hanya saat membaca pada halaman buku, Tidak melakukan pelanggaran, Hanya memfoto kopi/menyalin sesuai permintaan, Tidak pernah izin pencipta dan penerbit, Tidak pernah membeli royalti, Bukan merupakan tradisi ataupun kelaziman, Sudah bayar retribusi, Tidak pakai SIUP, hanya membayar sewa, Biasanya foto kopi buku full teks, semua buku, buku asing mapun lokal, Ada yang semacam ebook printing, Ada juga jurnal internasional printing, Prinsip memfoto kopi sesuai permintaan konsumen, termasuk jumlahnya, Persaingan tajam, Lebih suka memfoto kopidiktat, memfoto kopi buku ribet, harus bongkar dan lebih suka non buku dalam memfoto kopi (Hasil wawancara dengan pengusaha foto kopi di lingkungan Perguruan Tinggi, Maret 2015).

Menurut Budi, pemilik foto kopi "Gemilang“ yang mempunyai cabang di lingkungan kampus UNISBANK, selain itu juga memiliki usaha foto kopi di kawasan UNDIP Peleburan dan dikawasan Pumanisa UNISSULA, bahwa kegiatan memfoto kopi buku cenderung lebih banyak, tapi kalau di kawasan UNES lebih spesifiknya penggandaan Skripsi, Tesis dan Disertasi. Namun untuk kawasan di UNISBANK cenderung tidak banyak yang memfoto buku, sedangkan di UNDIP Peleburan lebih banyak memfoto kopi buku. Semuanya itu juga tidak lepas dari pada karakter dari para mahasiswa. Biasanya mahasiswa-mahasiswa yang rajin membaca lebih aktif untuk memfoto kopi khususnya mahasiswa UNDIP. Lebih lanjut dijelaskan bahwa pengusaha foto kopi secara umum membaca kondisi pasar, sehingga biasanya yang memiliki usaha foto kopi membuka cabang dibeberapa titik seperti misalnya yang memiliki foto kopi di UNDIP peleburan membuka cabang dikawasan Pumanisa UNISSULA, di lingkungan Kampus USM, UNISBANK dan juga di UNES serta hal ini juga dipicu banyaknya lapak-lapak buku aspal (asli tapi palsu), buku versi foto kopi dan buku bekas dikawasan stadion dan pasar johar.(Hasil wawancara Budi pemilik usaha poto kopi Gemilang, 25 Mei 2015).

Pada Universitas Kristen Satiyawacana Salatiga untuk usaha foto kopi di dalam kampusnya merupakan salah satu usaha dari para alumni yang berada didekat perpustakaan, namun ada beberapa masalah internal dengan pihak lembaga sehingga usaha foto kopi sekarang ini pindah tempat namun masih di dekat lingkungan kampus (Hasil wawancara dengan ibu Maya UKSW Salatiga, April, 2015).

Dengan demikian ketentuan fair use/fair dealing hak cipta atas buku sebagaimana diatur Pasal 44 Ayat (1) huruf a, huruf b dan huruf c yang lebih memberikan perlindungan hak moral pencipta. Kemudian ketentuan Pasal 46 ayat (1) dan ayat (2) huruf b dan huruf e lebih memberikan perlindungan hak ekonomi pencipta/pemegang hak cipta. Serta berdasarkan ketetntuan Pasal 47 UU Hak Cipta yang boleh melakukan penggadaan/memfoto kopi buku hanyalah lembaga perpustakaan. Maka dari itu tindakan para pengusaha foto kopitelah melanggar ketentuan fair use/fair dealing hak cipta. 


\section{Draf Model Model Fair Use/Fair Dealing Hak Cipta Atas Buku yang Memenuhi Aksebilitas, Murah Berkualitas}

Dalam rangka mencerdaskan kehidupan bangsa sebagai amanat Pasal 31UUD 1945guna membangun peradaban bangsa melalui pengembangan dan pemanfaatan ilmu pengetahuan dan teknologi, buku menjadi salah satu sarana utama dalam upaya mencerdaskan kehidupan bangsa dan pada akhirnya meningkatkan kesejahteraan umum.Dengan melihat sejarah munculnya Negara kesejahteraan pada dasarnya dikembangkan dalam konteks ekonomi pasar (market economy) dan dalam hubungannya dengan sistem ekonomi campuran (mixed economy). Peranan negara dalam konsep negara kesejahteraan adalah memodifikasi-kan berbagai kekuatan pasar (to modify the play of market forces)(Donald J. Moon (ed), 1988:22).

Konsep Negara Kesejahteraan Pancasila Negara atau Pemerintah berkewajiban untuk mengatur dan mengarahkan masyarakat sebagai satu kesatuan atau keluarga. Khususnya saat ini bangsa Indonesia sudah memasuki globalisasi ekonomi dan hukum (Aminuddin Ilmar,2012:17-18). Globalisasi telah merambah hampir di semua ranah kehidupan masyarakat, baik itu bidang ekonomi, politik, ilmu pengetahuan dan teknologi (IPTEK), budaya, pendidikan, dan lain-lain(Adi Sulistiyono,2005:1-2).

Indonesia dihadapkan pada tantangan mencapai sasaran Millenium Development Goal memberantas kemiskinan dan ketertinggalan kesehatan serta pendidikan. Pada akhir tahun 2015, Indonesia akan memasuki ASEAN Economic Community. Bila krisis finansial gobal telah berakhir pada tahun 2010, maka Indonesia harus cekatan menanggapi tantangan persaingan dari RRT, India, Asia Timur dan Kawasan Asia umumnya. Asia diperkirakan menjadi "lokomatif penarik gerbong ekonomi dunia” dalam 25 tahun mendatang (Emil Salim, 2010:158).

Dengan AEC Blueprint merupakan pedoman bagi negara-negara Anggota ASEAN untuk mencapai AEC 2015, dimana masing-masing negara berkewajiban untuk melaksanakan komitmen dalamblueprint tersebut. Di dalam AEC Blueprint memuat empat pilar utama, diantaranya yaitu: ASEAN sebagai kawasan dengan dayasaing ekonomi tinggi, dengan elemen peraturan kompetisi, perlindungan konsumen, hak atas kekayaan intelektual, pengembangan infrastruktur, perpajakan, dan e-commerse(Blueprint AEC 2015).

Emil Salim, mengatakan bahwa keunggulan daya saing Indonesia di abad XX yang bertumpu pada tenaga kerja tidak berlaku laku lagi, dengan masuknya RRT dan India yang memiliki tenaga kerja bermilyar-milyar merupakan saingan bagi Indonesia di masa depan. Oleh karena itu persaingan ekonomi dan tantangan pembangunan di masa depan Indonesia terletak dalam mengembangkan ilmu dan teknologi yang bisa menaikkan nilai tambah sumber alam hayati yang khas unik di daratan dan lautan Indonesia. Pengembangan ilmu dan teknologi yang strategis relevan mencapai cita-cita pembangunan bangsa tahun 2025.

Rektor ITB, Akhmaloka (2013) menjelaskan bahwa IPTEK sebagai penerobos kemajuan, mesin ekonomi dan cahaya pencerah. Pengembangan ipteks tampaknya membutuhkan peranan negara dan pasar sekaligus. Sejauh ini pengembangan ipteks di Indonesia masih bersandar pada pihak asing. Hal ini terlihat dari berbagai sektor ekonomi yang masih menggunakan ipteks impor. "Kebergantungan ipteks akan membuat Indonesia sulit menentukan masa depannya sendiri,dansecara kerlahan-lahan kedaulatannya. (http://www.itb.ac.id/news/3968.xhtml diakses pada tanggal 30 Juni 2015) 
Pancasila sebagai dasar negara (filsafat negara, ideologi negara, ideologi nasional) berfungsi sebagai jiwa bangsa dan jati diri nasional. Secara kenegaraan nilai pancasila adalah asas kerohanian bangsa, dan jiwa UUD Negara. Filsafat Pancasila memberikan kedudukan tinggi dan mulia atas potensi dan martabat manusia (sila I-II, Sila III, Sila IV dan Sila V), karena ajaran HAM berdasarkan Pancasila dijiwai dan dilandasi asas normatif TheismeReligius: bahwa HAM adalah karuna dan anugerah Maha Pencipta (Sila I dan Sila II), sekaligus amanat untuk dinikmati dan disyukuri oleh umat manusia, Bahwa menegakkan HAM senantiasa berdasarkan asas kesimbangan dengan Kewajiban Asasi Manusia (KAM), artinya HAM akan tegak hanya berkat(umat) manusia menunaikan KAM sebagai amanat Maha Pencipta, sebagai Integritas moral martabat manusia (TeguhPrasetyo,Abdul Halim Barakatullah,2012: 392-393).

Tegaknya ajaran HAM ditentukan oleh tegaknya asas kesimbangan HAM dan KAM, sekaligus sebagai derajat (kualitas) moral dan martabat (luhur) manusia. Keterbatasan akses masyarakat terhadap harga buku yang terjangkau, mutu, jenis, ketersediaan, dan pemanfaatan buku teks, buku pengayaan atau pelengkap, buku referensi, buku panduan pendidik, buku pengetahuan praktis, dan buku hiburan serta belum adanya kerangka hukum yang mengatur mengenai perbukuan secara menyeluruh berpengaruh terhadap upaya mencerdaskan kehidupan bangsa. Di samping itu, pelaku atau praktisi di bidang perbukuan saat ini belum mendapatkan perlindungan dan kepastian hukum secara optimal dalam menjalankan peran sertanya dalam upaya mencerdaskan kehidupan bangsa(Penjelasan Draf UU Sistem Perbukuan Nasional).

Fungsi hukum secara umum dapat diklasifikasikan dalam tiga tahap: Fungsi hukum sebagai alat ketertiban dan keteraturan masyarakat, Fungsi hukum sebagai sarana untuk mewujudkan keadilan sosial lahir batin dan Fungsi hukum sebagai sarana penggerak pembangunan (Soedjono Dirdjosisworo, 2012:154-155). Dengan demikian agar hukum dapat merealisasikan fungsinya sebagai sarana untuk menertibkan dan mengatur masyarakat pengguna buku, dalam menggerakkan pembangunan disegala bidang, khususnya pendidikan tinggi dalam mengisi kemerdekaan bangsa Indonesia dalam mencerdaskan kehidupan berbangsa dan bernegara dengan mewujudkan keadilan sosial lahir batin, diperlukan model fair use/fair dealing hak cipta atas buku dalam pengembangan IPTEK pada pendidikan tinggi yang berasaskan keseimbangan dan pemanfaatan.

Bagan Draf Model

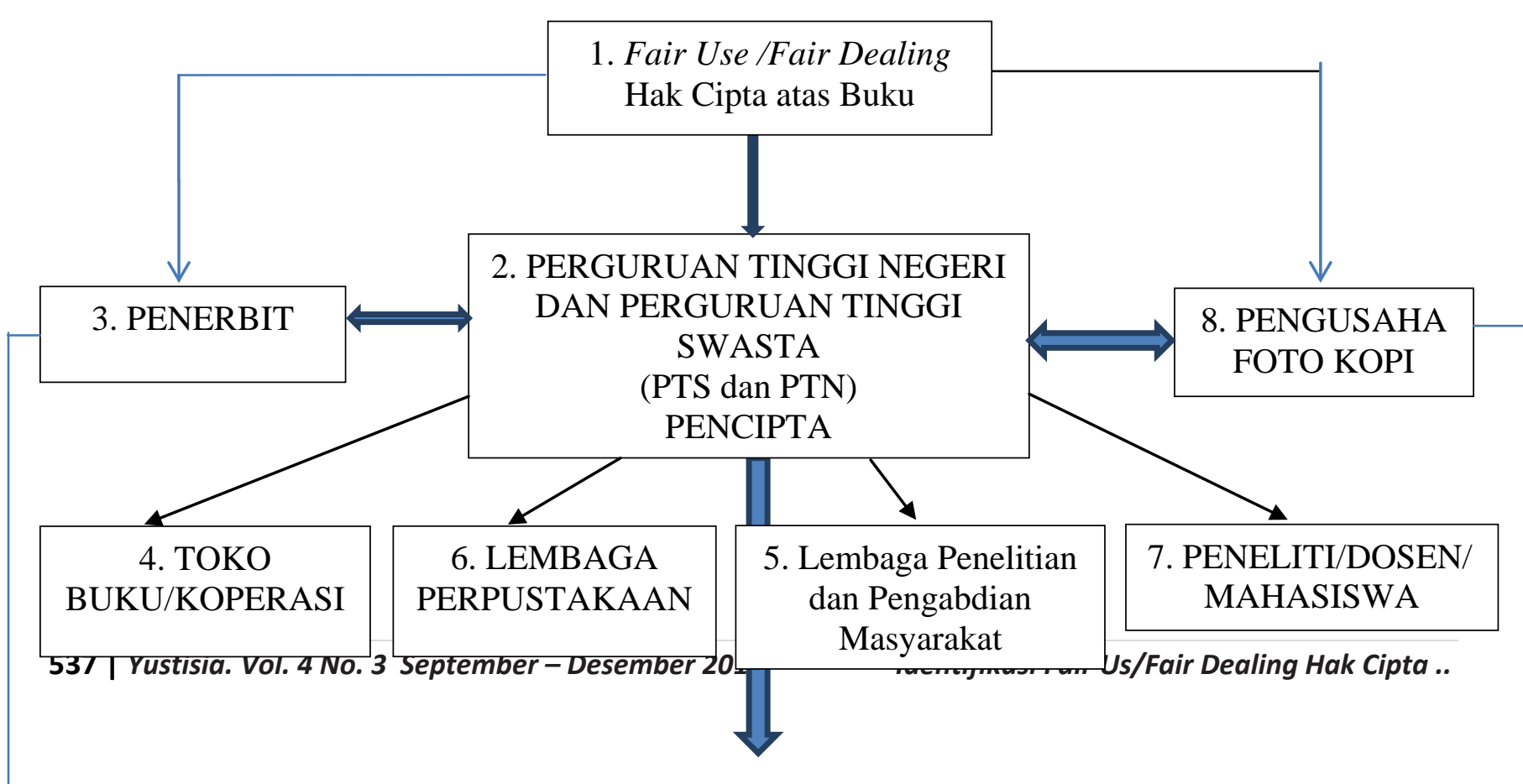




\section{Simpulan}

Implementasi fair use/fair dealing hak cipta atas buku dalam pengembangan IPTEK pada pendidikan tinggi di Jateng terkendala dengan beragamnya persepsi masyarakat pengguna buku di Salatiga, Kabupaten Semarang dan Kota Semarang. IKAPI selaku pemegang hak cipta belum bisa memberikan hak ekonomi pencipta/penulis buku yang layak, mengingat upah buku yang sedikit, reading habit dan kemampuan daya beli masyarakat rendah, belum terdistribusinya buku secara merata dan biaya operasional mencetak buku yang mahal. Perpustakaan belum dimanfaatkan sebagai pusat pengembangan dan penelitian, belum tersedianya kuantitas dan kualitas buku dalam semua bidang keilmuan baik buku lokal mapun asing, belum tersosialisasinya hasil-hasil penelitian secara luas serta belum dijadikan sebagai bahan ajar, perpustakaan dalam memfoto kopi berdasarkan pada kebutuhan, mahassiwa masih banyak yang memfoto kopi. Penulis buku belum mendapatkan penghargaan hak moral dan hak ekonomi yang layak, hal ini membuat lesunya untuk menulis buku sehingga lebih cenderung menulis artikel karena tidak begitu menguras pikiran dan waktu yang panjang, disisi lain masih dibajaknya buku serta kebiasaan memfoto kopi bagi mahasiswa dan dosen. Dosen dan mahasiswa masih memfoto kopi buku disebabkan karena akses buku asli yang sulit, harganya mahal dan tidak terjangkau, serta belum tersedianya toko buku di dalam kampus layaknya negara-negara luar negeri dan banyaknya pengusaha foto kopi dilingkungan kampus/universitas baik negeri maupun swasta. Pengusaha foto kopi, dalam memfoto kopi buku tidak pernah ijin kepada pencipta/penerbit selaku pemegang hak cipta atas buku, bahkan juga tidak memberikan royalti kepada pencipta/ penerbit selaku pemegang hak cipta atas buku, dalam memfoto kopi sesuai dengan permintaan konsumen (baik mahasiswa, dosen maupu masyarakat secara umum).

\section{E. Saran}

Pertama, perlunya memupuk kesadaran HKI (terkait hak cipta) yang tinggibagi masyarakat pengguna buku dalam memberikan penghargaan baik secara moral maupun secara ekonomi kepada pencipta, guna menumbuh kembangkan kreatifitas dan produktifitas yang berkualitas. Kedua, adanya sistem perbukuan nasional mendukung dan mendorong IKAPI dalam menerbitkan bukubuku yang berkualitas demi terwujudnya keseimbangan hak dan pemanfaatan buku secara luas. Ketiga, pemerintah agar bekerjasama dengan perguruan tinggi untuk melaksanakanPusat Penelitian dan Pengembangan IPTEK dan media belajar sepanjang hayat. Keempat, perlunya memberikan penghargaan yang tinggi kepada dosen sebagai penulis buku dengan syarat yang tidak terlalu ketat, guna melahirkan buku yang berkualitas dan adanya kebijakan perguruan tinggi yang mewajibkan setiap dosen menulis buku setiap tahunnya. Kelima, adanya berkerjasama dengan IKAPI selaku penerbit guna terjaminnya aksebilitas buku yang mudah, terjangkau dan berkualitas bagi masyarakat pengguna buku khususnya dosen, mahasiswa dan civitas akademika. Keenam,perlunya 
kebijakan modelfair use/fair dealing hak cipta atas buku dalam pengembangan IPTEK pada pendidikan tinggi di Jawa Tengah dengan berasaskan keseimbangan hak dan pemanfaatan buku yang menjamin aksebilitas buku berkualitas dalam bentuk buku teks dan e-Books dengan harga yang terjangkau.

\section{Daftar Pustaka}

Ajip Rosidi. 2006. Suatu Pengantar dalam terjemahan Buku Panduan Hak Cipta Asia Judul asli: Asian Copyright Handbook Oleh Tamotsu HOZUMI. Asia/Pacific Cultural Centre for UNESCO 2004 Penerjemah: Masri Maris Terbitan Pertama: April 2006 ISBN 979-96189-1-6 Diterbitkan oleh Asia/Pacific Cultural Centre for UNESCO (ACCU) dan Ikatan Penerbit Indonesia (Ikapi) Disponsori oleh Japan Copyright Office, Jepang.

Adi Sulistiyono. 2005. Reformasi Hukum Ekonomi Dalam Era Globalisasi Ekonomi. Surakarta: Sebelas Maret University Press.

Agus Sardjono. 2009. Membumikan HKI di Indonesia. Bandung: CV Nuansa Aulia.

Ali Mansyur. 2010. Aneka Persoalan Hukum (Masalah Perjanjian, Konsumen \& Pembaharuan Hukum). Cetakan Kedua. Semarang: Sultan Agung Press.

Aminuddin Ilmar. 2012. Hak Menguasai Negara dalam Privatisasi BUMN. Jakarta: Frenada Media Group.

Anis Mashdurohatun."Problematika Perlindungan Hak Cipta di Indonesia”. Jurnal Justisia Jurnal Hukum. Edisi 82. Januari-April 2011. Fakultas Hukum UNS. Surakarta.

2013.Mengembangkan Fungsi Sosial Hak Cipta Indonesia (Suatu Studi Pada Karya Cipta Buku). Disertasi. Program Doktor Ilmu Hukum Fakultas Hukum UNS. Surakarta.

Arief Hoetoro. 2007. Ekonomi Islam Pengantar Analisis Kesejahteran dan Metodologi. Surabaya: BPFE UNIBRAW.

Arif Sidharta. 2009.Meuwissen tentang Pengembangan Hukum, Ilmu Hukum, Teori Hukum, dan Filsafat Hukum. Cetakan Kesembilan. Bandung: Refika Aditama.

C.S.T. Kansil dan Cristine S.T. Kansil. 2011. Pengantar Ilmu Hukum Indonesia.Cetakan Pertama. Jakarta: Rineka Cipta.

Didiek Ahmad Supardie. 2015.Wakaf Mensejahterakan Umat.Semarang: Unissula Press.

Donald J. Moon (Ed.). 1988.Responsibility Rights and Welfare. Colorado: Westview Press. Inc. Boulder.

Dossy Iskandar Prasetyo dan Bernard L.Tanya. 2011. Hukum Etika \& Kekuasaan. Yogyakarta: Genta Publishing.

Draff RUU Sistem Perbukuan Nasional.

Elisabert Nurhaini Butarbutar. 2012. Hukum Harta Kekayaan Menurut Sistematika KUHPerdata dan Perkembangannya. Bandung: Refika Aditama.

Eman Suparman. 2012.Arbitrase dan Dilema Penegakan Keadilan. Jakarta: Fikahati Aneska bekerjasama dengan BANI Arbitration Center.

Emil Salim. 2010. Ratusan Bangsa Merusak Satu Bumi. Jakarta: PT Gramedia.

Eric M. Dobrusin, Ronald A. Krasnon. 2008. Intellectual Property Culture: Strategies to Foster Successful Patent and Trade Secreat Practices In Everyday Business.America: Oxford University.

Gatot Supramono. 2010. Hak Cipta dan Aspek-Aspek Hukumnya.Jakarta: PT Rineka Cipta.

Hayyan ul Haq. 2011. Legal Instruments for an Optimal Utilization of Information and Technology under the Intellectual Property Regime: A Study on the Implication of the Creator and Inventor Doctrine for the Utilization of Intellectual Products through Technology Transfer for the Greatest Benefit of People in Indonesia. Nederland: Utrecht University.

http://www.itb.ac.id/news/3968.xhtml diakses pada tanggal 30 Juni 2015.

Imam Sjahputra. 2007. Hak Atas Kekayaan Intelektual (Suatu Pengantar). Jakarta Harvarindo. 
Moh. Mahfudz MD. 2009.Politik Hukum di Indonesia. Jakarta: Rajawali Press.

Peraturan Pemerintah Republik Indonesia Nomor 24 Tahun 2014 tentang Pelaksanaan UndangUndang Nomor 43 Tahun 2007 tentang Perpustakaan.

Sanusi Bintang.1998. Hukum Hak Cipta. Bandung: Citra Aditya Bakti.

Soedjono Dirdjosisworo. 2012. Pengantar Ilmu Hukum. Cetakan keduabelas. Jakarta: PT RajaGrafindo Persada.

Teguh Prasetyo dan Abdul Halim Barakatullah. 2012. Filsafat, Teori, \& Ilmu Hukum: Pemikiran Menuju Masyarakat yang berkeadilan dan Bermartabat. Jakarta: Rajawali Press.

Undang-Undang Republik Indonesia Nomor 28 Tahun 2014 tentang Hak Cipta.

Undang-Undang Republik Indonesia Nomor 40 Tahun 2007 tentang Perseroan Terbatas

Undang-Undang Republik Indonesia Nomor 43 Tahun 2007 tentang Perpustakaan. 